\title{
Expression of thioredoxin in granulomas of sarcoidosis: possible role in the development of T lymphocyte activation
}

Toshiya Koura, Yasuhiro Gon, Shu Hashimoto, Arata Azuma, Shoji Kudoh, Yuh Fukuda, Isamu Sugawara, Junji Yodoi, Takashi Horie

\begin{abstract}
Background-Activated $T$ lymphocytes are one of the characteristic features of sarcoidosis. The mechanism of $T$ cell activation, expressing various activation markers including interleukin 2 receptor (IL-2R), has been extensively investigated but the precise mechanism remains unknown. Although thioredoxin (TRX) displays a number of biological activities including IL-2R inducing activity, its role in the induction of IL-2R expression on T cells in sarcoidosis has not been determined. The expression of TRX and IL-2R in granulomas of patients with sarcoidosis has been studied to clarify a possible role for TRX in the induction of IL-2R expression.
\end{abstract}

Methods-Granulomas in specimens of lung tissue and lymph nodes from five patients with sarcoidosis were immunohistochemically stained with anti-TRX antibody and anti-IL-2R $\alpha$ chain antibody and the concentration of TRX in the bronchoalveolar lavage (BAL) fluid from 20 patients with pulmonary sarcoidosis was measured.

Results-Granulomas in lung and lymph node tissue from patients with sarcoidosis showed strong reactivity with anti-TRX antibody. Positive staining was present in the macrophages, epithelioid cells, and Langhans' type giant cells but not in lymphocytes. IL-2R was expressed on lymphocytes in the same granulomas. By contrast, positive immunoreactivity was not found in lung tissue specimens from 12 control subjects. Concentrations of TRX in BAL fluid were higher in patients with pulmonary sarcoidosis (median (range) $122.6(20.9-303.3) \mathrm{ng} / \mathrm{ml}$ ) than in control subjects (32.9 (16.8-52.8) ng/ml, p<0.05). Conclusions-TRX is highly expressed and is locally produced by granulomas in patients with sarcoidosis. The coexistence of immunoreactive TRX and IL-2R in the same granulomas suggests that TRX might act as a local inducing factor for IL-2R expression on $T$ cells. (Thorax 2000;55:755-761)

Keywords: thioredoxin; sarcoidosis; granulomas; IL-2Ro

Sarcoidosis is a systemic granulomatous disorder of unknown origin characterised by a chronic $\mathrm{T}$ lymphocyte/macrophage inflamma- tory process, granuloma formation, and distortion of normal architecture. ${ }^{12}$ It is characterised, at least in part, by the accumulation of activated $\mathrm{T}$ lymphocytes and macrophages in the affected organ. ${ }^{12}$ The activated T cells are primarily of the CD4 positive phenotype and express various activation markers on their cell surface including interleukin 2 receptor (IL-2R). ${ }^{1-4}$ Although it has been suggested that activation of CD4 positive $\mathrm{T}$ cells is a pivotal step in the events leading to the formation of granulomas in sarcoidosis, ${ }^{12}$ its aetiology and the precise mechanism of $\mathrm{T}$ cell activation at the disease sites are still unknown.

Human thioredoxin (TRX) was initially identified from the culture supernatants of an HTLV-1 infected cell line as an IL-2R $\alpha$ chain/ Tac inducer. ${ }^{56}$ Cloning of the cDNA of this factor, ATL derived factor (ADF), showed that it is a human homologue of sulfhydryl reducing enzyme, TRX, first found in prokaryocytes. ${ }^{78}$ There is increasing evidence that TRX has a variety of biological activities ${ }^{9}$ including synergism of IL-1 and IL-2 induced proliferation of Epstein-Barr virus transformed B cells, ${ }^{10}$ enhancement of the proliferative response of lymphocytes to IL-2, ${ }^{11}$ and the binding of several transcriptional factors including $\mathrm{AP}-1$ and $\mathrm{NF}-\kappa \mathrm{B} .{ }^{12-14}$ Thus, TRX may play a crucial role in lymphocyte activation including IL-2R expression and proliferation. However, its role in the induction of IL-2R expression on lymphocytes in patients with sarcoidosis has not been determined. We have therefore immunohistochemically stained granulomas from patients with sarcoidosis with anti-human TRX antibody and measured the concentrations of TRX in bronchoalveolar lavage (BAL) fluid to assess the role of TRX in sarcoidosis. We simultaneously stained the granuloma tissue with anti-IL-2R antibody to determine its IL-2R inducing activity.

\section{Methods}

STUDY POPULATION

The study group comprised 20 consecutive non-smoking patients with pulmonary sarcoidosis (12 men) of mean age 40 years (range 20-75). The diagnosis of sarcoidosis was established by clinical and radiographic findings and histological evidence of non-caseating granulomas from diagnostic lung biopsy specimens taken by transbronchial, thoracoscopic, or open biopsies. Active sarcoidosis at the time the biopsy specimen was taken was determined by the following criteria ${ }^{1-315}:(1)$ an increase in 
Table 1 Characteristics of patients with sarcoidosis

\begin{tabular}{|c|c|}
\hline Number of subjects & 20 \\
\hline Age (years) & $40.4(16.0)$ \\
\hline $\operatorname{Sex}(F: M)$ & $8: 16$ \\
\hline \multicolumn{2}{|l|}{ Chest radiographic stage $\dagger$} \\
\hline Stage 0 & 1 \\
\hline Stage I & 8 \\
\hline Stage II & 9 \\
\hline Stage III & 2 \\
\hline \multicolumn{2}{|l|}{ Lung function testing } \\
\hline $\mathrm{FEV}_{1.0}(\%$ predicted $)$ & $78.1(14.3)$ \\
\hline FVC (\% predicted) & $101.1(18.0)$ \\
\hline TLCO (\% predicted) & $97.1(27.4)$ \\
\hline $\mathrm{PaO}_{2}(\mathrm{~mm} \mathrm{Hg})$ & $82.4(11.1)$ \\
\hline \multicolumn{2}{|l|}{ Bronchoalveolar lavage $\ddagger$} \\
\hline$\%$ recovery & $68.2(10.1)$ \\
\hline Total BAL cell count $\left(10^{3} / \mathrm{ml}\right)$ & $495.2(151.1)$ \\
\hline Lymphocytes (\%) & $32.0(20.2)$ \\
\hline $\mathrm{CD} 4 / \mathrm{CD} 8$ ratio & $5.0(2.8)$ \\
\hline Serum ACE (IU/1) & $31.2(18.5)$ \\
\hline
\end{tabular}

Results are expressed as mean (SD).

$\mathrm{FEV}_{1.0}=$ forced expiratory volume in one second $\mathrm{FVC}=$ forced vital capacity; $\mathrm{T}_{\mathrm{LCO}}=$ carbon monoxide transfer factor; $\mathrm{BAL}=$ bronchoalveolar lavage; $\mathrm{ACE}=$ angiotensin converting enzyme. †Stage $0=$ normal radiograph; stage $\mathrm{I}=$ bilateral lymphadenopathy; stage II = bilateral lymphadenopathy with parenchymal infiltration; stage III = solely parenchymal infiltration.

$\ddagger$ In the 10 control subjects percentage recovery, percentage of lymphocytes in all cells recovered by BAL, and CD4/CD8 ratio were $70.1(10.1) \%, 4.2(1.8) \%$, and $1.4(0.6)$, respectively.

lymphocytes in the BAL fluid and an increased CD4/CD8 ratio of lymphocytes in BAL fluid; (2) increased levels of serum angiotensin converting enzyme; and (3) positivity to 67-labelled gallium scan. On the basis of these criteria, all patients in this study were regarded as having active disease; one had pulmonary involvement proved by lung biopsy with normal radiography (radiographic stage 0); eight had bilateral hilar lymph node (BHL) enlargement (stage I); nine had BHL and parenchymal shadowing (stage II); and two had parenchymal shadowing without BHL (stage III). The characteristics of the patients are summarised in table 1 . None of the patients had been treated with corticosteroids.

For immunohistochemical analysis, histologically normal specimens of lung tissue from eight patients (four men) of mean age 63 years (range 51-68) who had undergone surgery for lung cancer (all patients had adenocarcinoma) and from four patients (two men) of mean age 30 (range 26-48) who underwent surgery for pneumothorax because of localised bulla were used as controls. For the determination of TRX concentrations in BAL fluid, four patients with lung adenocarcinoma (two men) of mean age 57 (range 39-68) and six patients with haemoptysis (two men) of mean age 31 years (range 26-58) were recruited as controls.

Neither the patients nor the control subjects had ever smoked. Informed consent was obtained from all subjects participating in the study.

DESIGN OF STUDY

BAL fluid was obtained by the standard technique. Briefly, the lingula or right middle lobe of patients with pulmonary sarcoidosis was washed with $150 \mathrm{ml}$ saline prewarmed to $37^{\circ} \mathrm{C}$. Recovered BAL fluid was filtered through two layers of sterile gauze, centrifuged at $1.500 \mathrm{rpm}$, and the supernatants were collected and stored at $-70^{\circ} \mathrm{C}$ until assay. BAL fluid was recovered from the opposite side of the lung in patients with localised lung carcinoma. In those with haemoptysis, BAL fluid was recovered from the right middle lobe or lingula after confirming by bronchoscopic examination that there were no abnormalities of the bronchial mucosa.

IMMUNOHISTOCHEMICAL ANALYSIS

Immunohistochemical analysis of TRX and IL-2R expression was performed using the immunoperoxidase technique. Serial tissue sections were deparaffinised in toluene and dehydrated in graded alcohol. Deparaffinised sections were treated with $3 \% \mathrm{H}_{2} \mathrm{O}_{2}$ in absolute methanol to inhibit endogenous peroxidase for 20 minutes and then incubated with normal horse serum immunoglobulin for 10 minutes to block non-specific antibody binding. The primary antibody was mouse anti-human TRX monoclonal IgG antibody which was established by immunising Balb/c mice with recombinant human TRX (rTRX) (Fujirebio Inc, Tokyo, Japan) for analysis of TRX expression or rabbit anti-IL-2Ra chain polyclonal IgG antibody (Santa Cruz, Santa Cruz, California, USA) for analysis of IL-2Ra. For analysis of TRX expression the sections were incubated for two hours with the primary antibody or the primary antibody that had been pretreated with saturable rTRX for the absorption procedure. For analysis of IL-2R $\alpha$ the sections were incubated for two hours with the primary antibody or with non-immune normal rabbit IgG as a negative control. Thereafter, the sections were incubated with the secondary antibody (biotinylated and affinity purified anti-mouse IgG) for 30 minutes, followed by incubation with avidin-biotin amplification for $30 \mathrm{~min}$ utes, and stained with a solution containing 3-amino-9 ethylcarbazole and $0.15 \% \mathrm{H}_{2} \mathrm{O}_{2}$.

All the reagents except the primary antibody were obtained from Histostain SP Kit (Zymed Laboratories Inc, San Francisco, California, USA). Counterstaining was performed with haematoxylin. To evaluate TRX and IL-2R expression, two different investigators blindly analysed at least five sections for each case.

MEASUREMENT OF TRX CONCENTRATIONS IN BAL FLUID

TRX was measured by a sandwich ELISA using two monoclonal antibodies (ADF21 and ADF11) which recognised different epitopes of TRX (Fujirebio Inc, Tokyo, Japan). ELISA was performed as described previously. ${ }^{16}$ Monoclonal antibodies were purified from the ascites of $\mathrm{BALB} / \mathrm{c}$ mice injected intraperitoneally with hybridoma producing monoclonal antibodies to human recombinant TRX by fractionation with ammonium sulfate precipitation, followed by $\mathrm{ABx}$ column (Bakerbond, Mallinckrodt Baker, Philipsburg, New Jersey, USA). ADF21 antibody immobilised plates were incubated with $100 \mathrm{ml}$ of the sample in $100 \mathrm{ml}$ of first reaction buffer $(50 \mathrm{mmol} / \mathrm{l}$ Tris- $\mathrm{HCl}$ buffer, $\mathrm{pH}$ 7.5, containing $1.0 \%$ bovine serum albumin and $0.1 \% \mathrm{NaN}_{3}$ ) for two hours at room temperature. The plates were washed five times with $0.85 \% \mathrm{NaCl}$ and were then incubated with $100 \mathrm{ml}$ horseradish peroxidase conjugated 

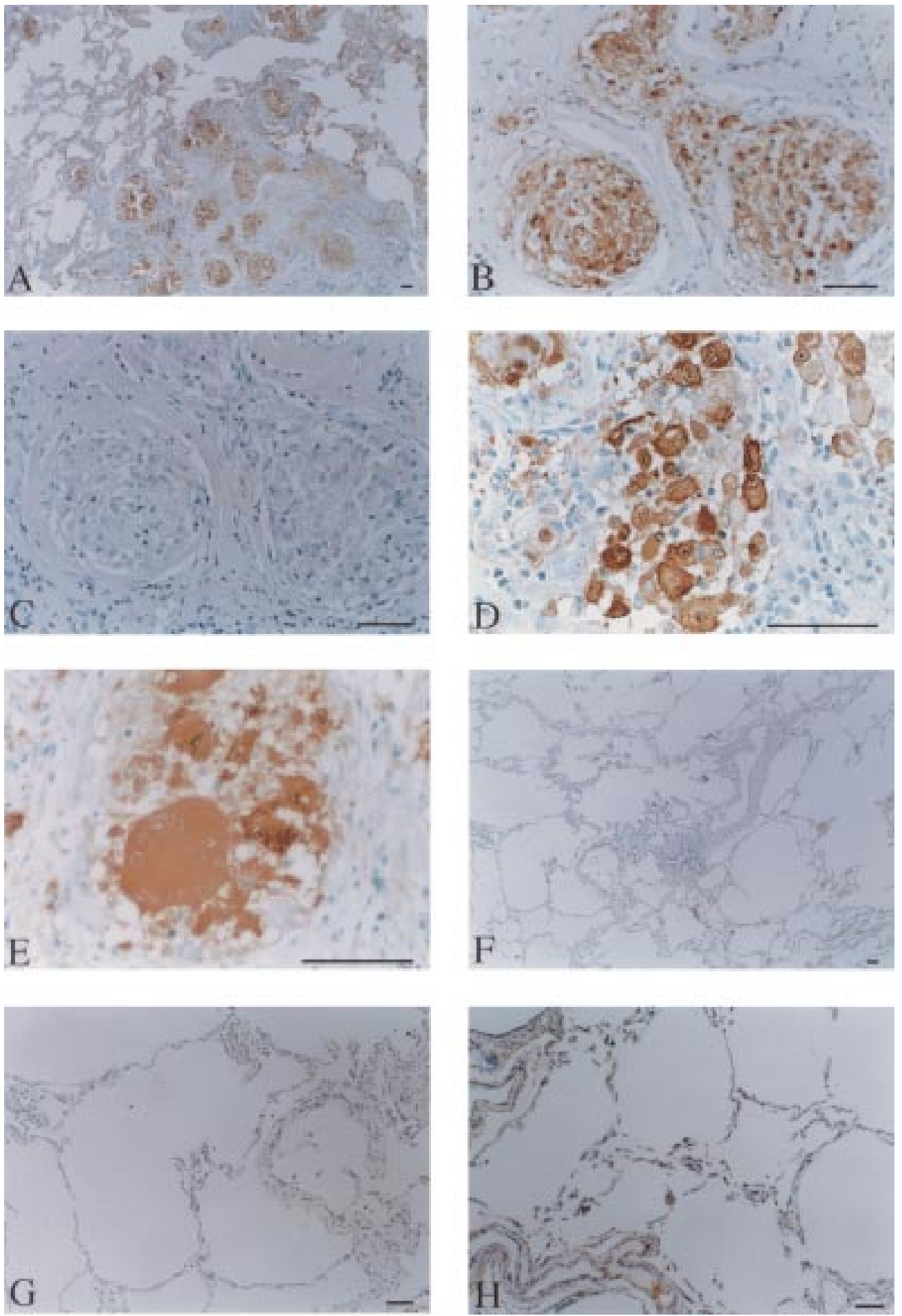

Figure 1 TRX expression in the granulomas of lung tissue specimens from patients with sarcoidosis. (A) Low magnification: TRX is highly expressed in the granuloma (original magnification $\times 40$ ). (B) Higher magnification: TRX is diffusely stained inside the granuloma (original magnification $\times 200$ ). (C) Reduced immunoreactivity of the granuloma after absorption of anti-TRX antibody with excess human $r T R X$ (original magnification $\times 200$ ). TRX is positively stained in (D) macrophages and epithelioid cells and (E) Langhans'type giant cells (original magnification $\times 400)$. (F) and $(G)$ TRX expression is not found in histologically normal lung tissue from patients with lung carcinoma (controls) ( $F$, original magnification $\times 40$; $G$, original magnification $\times 100)$ nor in $(H)$ histologically normal lung tissue from patients with pneumothorax (controls) (original magnification $\times 100$ ). Bars $=50 \mathrm{~mm}$.

ADF11 for one hour at room temperature. After incubation the plates were washed again; $100 \mathrm{ml}$ of substrate solution $(150 \mathrm{mmol} / \mathrm{l}$ citrate phosphate buffer, $\mathrm{pH} 4.2$, containing $0.2 \% \mathrm{H}_{2} \mathrm{O}_{2}$ and $0.13 \%$ ABTS) was added and incubated for one hour at room temperature. The reaction was then stopped by the addition of $100 \mathrm{ml} 1 \%$ oxsaloric acid solution and the absorbance at $405 \mathrm{~nm}$ was measured in an ELISA reader.

STATISTICAL ANALYSIS

Statistical significance was analysed using the Mann-Whitney U test. A p value of $<0.05$ was considered significant. 

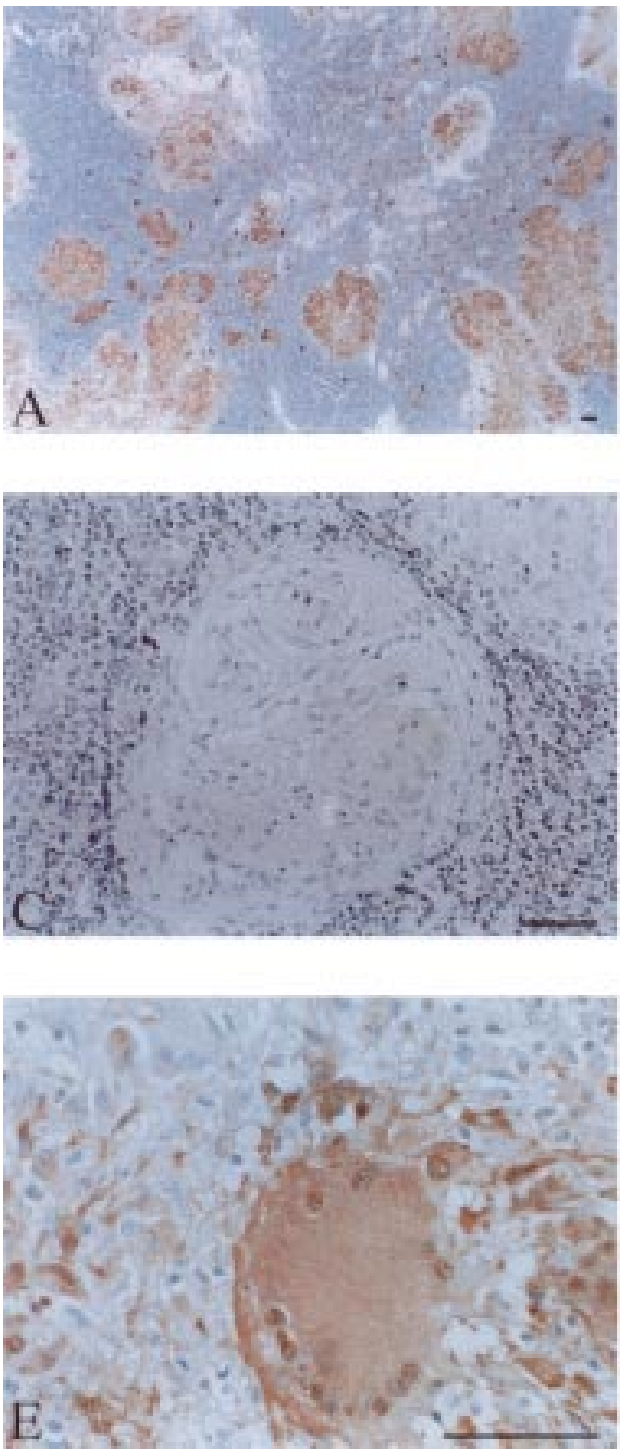

\section{Results}

TRX IN SARCOIDOSIS

Five specimens of lung tissue and five lymph nodes from patients with sarcoidosis were stained with anti-TRX antibody. Representative results are shown in figs 1 and 2. TRX was highly stained in the granulomas and diffusely stained inside the granulomas of lung tissue specimens (fig $1 \mathrm{~A}$ and $\mathrm{B}$ ). Positive staining was present in the macrophages, epithelioid cells, and Langhans' type giant cells but not in lymphocytes (fig $1 \mathrm{C}$ and D). TRX was positively stained in granulomas of all other sections. Similar observations were seen in all sections of lung tissue from other patients. Similarly, in the granulomas of lymph nodes from patients with sarcoidosis TRX was highly stained and diffusely stained inside the granulomas (fig 2A and B), and macrophages, epithelioid cells, and Langhans' giant cells were positively stained with anti-TRX antibody (fig $2 \mathrm{D}$ and $\mathrm{E}$ ). TRX was positively stained in the granulomas of all other sections. Similar observations were obtained in all sections of the lymph nodes from other patients. No significant immunostaining was detected in granulomas in the lung tissue and
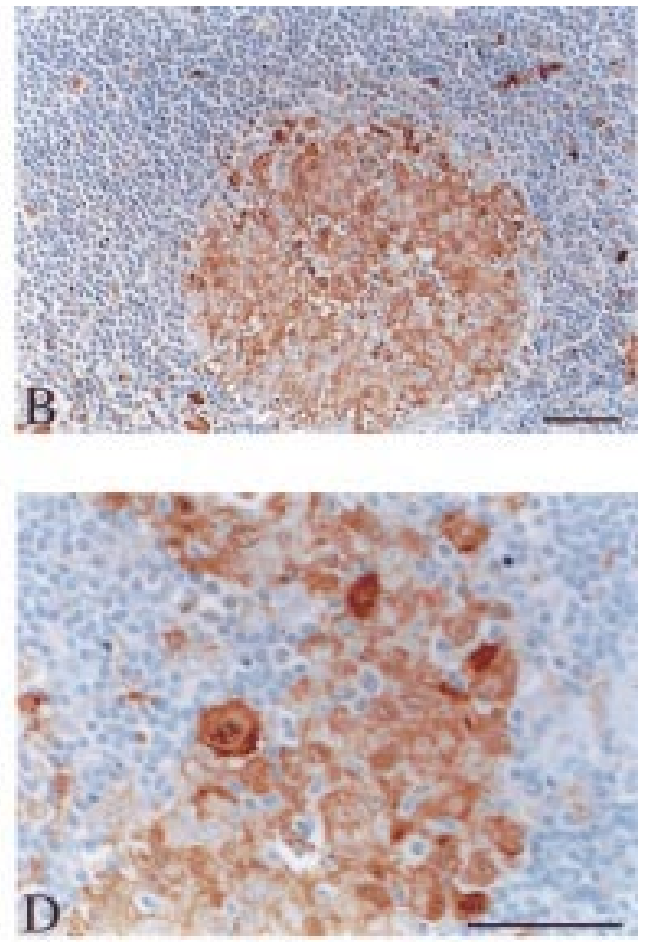

Figure 2 TRX expression in the granulomas of lymph nodes from patients with sarcoidosis. (A) Low magnification: TRX is highly expressed in granuloma (original magnification $\times 40$ ). (B) Higher magnification: TRX is diffusely stained inside the granuloma (original magnification $\times 200$ ). (C) Reduced immunoreactivity of granuloma after absorption of anti-TRX antibody with excess human $r T R X$ (original magnification $\times 200$ ). TRX is positively stained in (D) macrophages and epithelioid cells and (E) Langhans' type giant cells (original magnification $\times 400$ ). Bars $=50 \mathrm{~mm}$.

lymph nodes of patients with sarcoidosis when they were stained with anti-TRX antibody that had been preincubated with saturable rTRX (fig $1 \mathrm{G}$ and fig 2C), nor was any significant immunostaining detected in histologically normal lung tissue specimens from control subjects stained with anti-TRX antibody (fig $1 \mathrm{~F}, \mathrm{G}$ and $\mathrm{H})$.

\section{IL-2R $\alpha$ IN SARCOIDOSIS}

Five specimens of lung tissue and five lymph nodes from patients with sarcoidosis were stained with anti-IL-2R $\alpha$ antibody. Representative results are shown in fig 3 . IL-2R $\alpha$ was positively stained in lymphocytes of granulomas in all lung tissue specimens (fig $3 \mathrm{~A}$ and $\mathrm{B}$ ) and lymph nodes (fig $3 \mathrm{E}$ and $\mathrm{F}$ ). All sections of lung and lymph nodes from the other patients gave similar results. No significant immunostaining was detected in granulomas of lung tissue and lymph nodes stained with control antibody (normal rabbit IgG; fig 3C and G) nor in histologically normal lung tissue specimens from control subjects stained with anti-IL-2R $\alpha$ antibody (fig $3 \mathrm{D}$ and $\mathrm{H}$ ). 

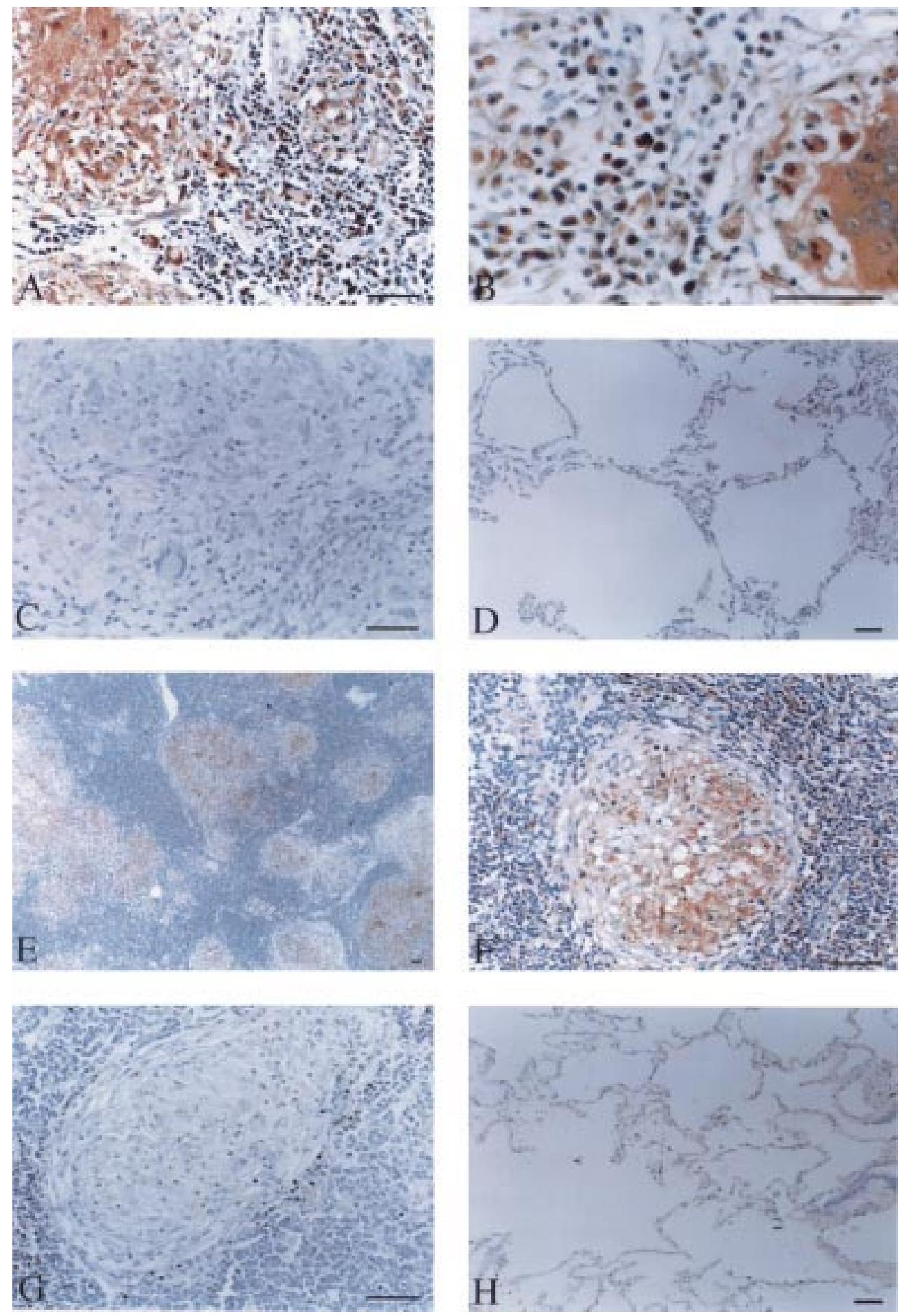

Figure 3 IL-2Ra expression in granulomas of lung tissue specimens and lymph nodes of patients with sarcoidosis. (A) Low magnification:IL-2Ra is highly expressed in gramulomas of lung tissue specimens (original magnification $\times 200$ ). (B) Higher magnification: IL-2Ra is positively stained in lymphocytes (original magnification $\times 400$ ). (C) Negative control with normal rabbit IgG (original magnification $\times 200$ ). (D) IL-2Ra expression is not found in histologically normal lung tissue specimens from patients with lung carcinoma (controls) (original magnification $\times 100$ ). (E) Low magnification: IL-2Ra is highly expressed in the granuloma of lymph nodes (original magnification $\times 40$ ). (F) Higher magnification: IL-2Ra is positively stained in lymphocytes (original magnification $\times 200$ ). (G) Negative control with normal rabbit IgG (original magnification $\times 200$ ). (H) IL-2Ra expression is not found in histologically normal lung tissue specimens from patients with pneumothorax (controls) (original magnification $\times 100$ ). Bars $=50 \mathrm{~mm}$.

TRX CONCENTRATIONS IN BAL FLUID

BAL fluid from patients with sarcoidosis contained more TRX (median 122.6 (range 20.9303.3) $\mathrm{ng} / \mathrm{ml}$ ) than that from control subjects (32.9 (range 16.8-52.8) $\mathrm{ng} / \mathrm{ml} ; \mathrm{p}<0.05$; fig 4A). Similar results were obtained when BAL fluid corrected for albumin concentration was analysed (sarcoidosis: median 15.3 (range 4.3-38.9) $\mathrm{ng} / \mu \mathrm{g}$ albumin; controls: 5.2 (range 1.7-9.1) $\mathrm{ng} / \mu \mathrm{g}$ albumin; $\mathrm{p}<0.01$; fig $4 \mathrm{~B}$ ). These results indicate that TRX in granulomas is actually secreted in the microenviron- 

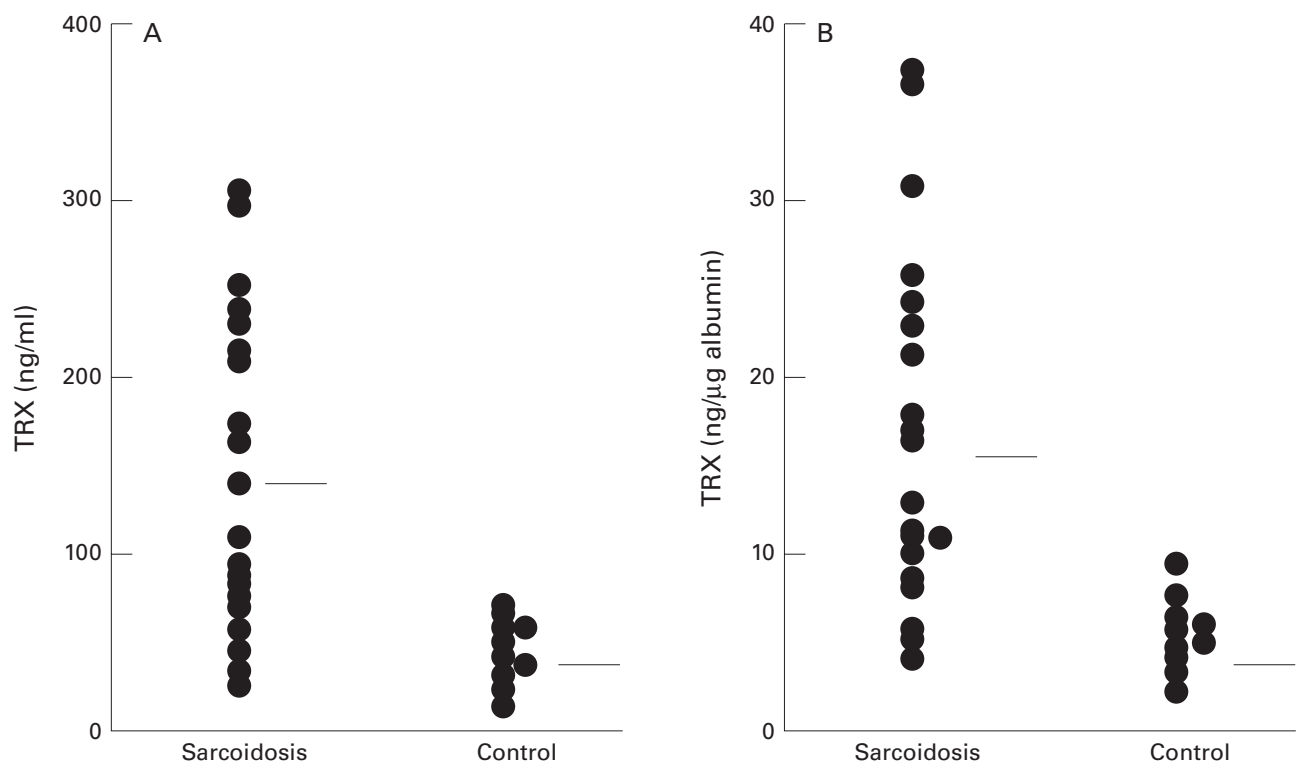

Figure 4 TRX concentrations in (A) $\mathrm{ng} / \mathrm{ml}$ and (B) $\mathrm{ng} / \mu \mathrm{g}$ albumin in BAL fluid from patients with sarcoidosis and control subjects. The horizontal lines represent median values of each group.

ment of the granuloma. TRX concentrations in BAL fluid correlated with the absolute number of lymphocytes $(r=0.68, \mathrm{p}<0.05)$, the percentage of lymphocytes in BAL fluid $(r=$ $0.66, \mathrm{p}<0.05)$, and with the $\mathrm{CD} 4 / \mathrm{CD} 8$ ratio of lymphocytes in BAL fluid $(r=0.60, \mathrm{p}<0.05)$.

\section{Discussion}

Immunostaining with anti-TRX antibody of granulomas in the lung and lymph node tissue of patients with sarcoidosis showed strong reactivity. Positive staining was present in the macrophages, epithelioid cells, and Langhans' type giant cells but not in lymphocytes. IL-2R $\alpha$ was expressed on lymphocytes in the granulomas. In contrast, positive immunoreactivity was not found in the lung tissue specimens from control subjects. These results show that positive staining of TRX is specific for granulomas from patients with sarcoidosis and that immunoreactive TRX and IL-2R coexist in the granulomas of these patients. In addition, the concentration of TRX in BAL fluid was higher in patients with pulmonary sarcoidosis than in control subjects.

Increased expression of IL-2R on $\mathrm{T}$ cells at the site of disease activity is well documented ${ }^{3}$; however, the mechanism of induction of IL-2R on T cells has not been clarified. Several mechanisms have been considered. Firstly, macrophage derived cytokines including IL-1 may play a part in the induction of IL-2R expression on T cells since IL-1, which has IL-2R inducing activity,${ }^{17}$ is reported to be preferentially expressed on macrophages in sarcoid granulomas. ${ }^{18}{ }^{19}$ Secondly, IL-2 may involve the induction of IL-2R expression since IL-2 per se can induce its receptor on $\mathrm{T}$ cells $^{20}$ and an increased expression of IL-2 on T cells in sarcoid granulomas. ${ }^{21} 22$ Thirdly, antigen presentation to $\mathrm{T}$ cells by macrophages may lead to $\mathrm{T}$ cell activation resulting in IL-2R induction since antigenic triggering of the $\mathrm{T}$ cell receptor has been reported. ${ }^{23}{ }^{24}$ In any case, the production of cytokines that activate $\mathrm{T}$ cells during macrophage activation and activation of antigen presenting cells including macrophages seems to be a pivotal step in the induction of IL-2R expression on $\mathrm{T}$ cells. However, the aetiology of sarcoidosis and the mechanism of activation of macrophages are still unknown. In this study we have shown that positive staining of TRX on macrophages and epithelioid cells and positive staining of IL-2R on lymphocytes were present in the same granulomas in patients with sarcoidosis. In addition, the concentrations of TRX in BAL fluid were higher in patients with pulmonary sarcoidosis than in controls. Since TRX has been shown to induce lymphocyte activation including IL-2R expression, ${ }^{56}$ these results indicate that local production of TRX may involve the induction of IL-2R expression.

TRX is reportedly a stress inducible protein. Its expression can be induced by a variety of oxidative stresses such as treatment with hydrogen peroxide, $x$ rays and UV irradiation, virus infection, and stimulation with tumour necrosis factor- $\alpha .^{8925}$ In addition, the mitogenic stimulation of lymphocytes and the stimulation of macrophages with interferon $\gamma$ (IFN- $\gamma$ ) induce TRX expression on each cell. $^{26}{ }^{27}$ We have shown TRX expression on macrophages and epithelioid cells that originated from monocyte lineage- - that is, macrophages. There are several possible mechanisms by which TRX is induced on macrophages and epithelioid cells. Alveolar macrophages in patients with sarcoidosis have been reported to release more reactive oxygen species and to express manganese superoxide dismutase. ${ }^{28} 29$ Under these circumstances an oxidative stress inducible protein such as TRX is likely to be induced, while the implication of oxidative stress in sarcoidosis has not been clarified. IFN- $\gamma$, which has been described as playing an important part in granuloma formation in sarcoidosis, is positively expressed in these 
granulomas. ${ }^{19}{ }^{30}$ It is capable of inducing $\mathrm{TRX}^{25}$ so may play a role in the induction of TRX expression on macrophages and epithelioid cells. However, the precise mechanism of this induction is not known.

We thought it of interest to determine whether the increased concentration of TRX found in patients with sarcoidosis is a result of the disease or a contributory factor to it. We analysed the relationship between TRX concentrations in BAL fluid and the absolute number and the percentage of lymphocytes and the CD4/CD8 ratio of lymphocytes in BAL fluid. The results showed that TRX concentrations correlated with the absolute number of lymphocytes, the percentage of lymphocytes, and CD4/CD8 ratio of lymphocytes in the BAL fluid, indicating a close linkage between TRX concentrations and disease activity. $T$ cells expressed IL-2R which are capable of binding IL- 2 and IL- 15 proliferate in response to IL-2 and IL-15. ${ }^{31}$ The accumulation of activated $T$ cells represents the pivotal step in the events leading to granuloma formation. Since TRX has been shown to enhance the proliferative response of lymphocytes to IL-2 and IL-2R inducing activity, increased TRX concentrations may contribute to lymphocyte proliferation. This hypothesis is supported by the correlation of TRX concentrations with the absolute number and percentage of lymphocytes in BAL fluid. Collectively, TRX may act as a contributory factor to the pathogenesis of sarcoidosis rather than a result of this disease. However, further studies are needed to determine whether the increased level of TRX found in patients with sarcoidosis is a result of the disease or a contributory factor to it.

In conclusion, we have found high TRX immunoreactivity in the granulomas of lung and lymph node tissue in patients with sarcoidosis. TRX was prominent in macrophages, epithelioid cells, and Langhans' type cells, and IL-2R was also positively stained in these granulomas. In addition, the concentration of TRX in BAL fluid was increased. These results indicate that TRX, which has IL-2R inducing activity, may play a part in the induction of IL-2R expression on T cells at the sites of disease activity in patients with sarcoidosis. However, the mechanism of induction and the precise role of TRX in sarcoidosis remain to be clarified.

1 Crystal RG, Roberts WC, Hunninghake GW, et al. Pulmonary sarcoidosis: a disease characterized and perpetuated by activated lung T-lymphocytes. Ann Intern Med 1981;94:73-94.

2 Thomas PD, Hunninghake GW. Current concepts of the pathogenesis of sarcoidosis. Am Rev Respir Dis 1987;135 $747-60$.

3 Muler-Quernheim J, Kronke M, Strausz J, et al. Interleukin-2 receptor gene expression by bronchoalveola lavage lymphocytes in pulmonary sarcoidosis. Am Rev Respir Dis 1989;140:82-8.

4 Semenzato G, Agostini C, Trentin L, et al. Evidence of cells bearing interleukin-2 receptor at sites of disease activity in sarcoid patients. Clin Exp Immunol 1984;57: 331-7.

5 Teshigawara K, Maeda K, Nishino K, et al. Adult T leukemia cells produce a lymphokine that augments interleukin 2 receptor expression. F Mol Cell Immunol 1985;2: $17-26$. 6 Okada M, Maeda M, Tagaya Y, et al. TCGF (IL-2) -receptor inducing factor(s). II. Possible role of ATLderived factor (ADF) on constitutive IL-2 receptor expres-
sion of HTLV-I (+) T cell lines. F Immunol 1985;135:39954003.

7 Tagaya Y, Maeda Y, Mitsui A, et al. ATL-derived factor (ADF), an IL-2 receptor/Tac inducer homologous to thioredoxin; possible involvement of dithiol-reduction in the IL-2 receptor induction. EMBO f 1989;8:757-64.

8 Yodoi J, Uchiyama T. Diseases associated with HTLV-I: virus, IL-2 receptor dysregulation and redox regulation. Immunol Today 1992;13:405-11.

9 Nakamura H, Nakamura K, Yodoi J. Redox regulation of cellular activation. Annu Rev Immunol 1997;15:351-69.

10 Wakasugi $\mathrm{N}$, Tagaya $\mathrm{Y}$, Wakasugi $\mathrm{H}$, et al. Adult T-cell leukemia-derived factor/thioredoxin produced by both human T-lymphotropic virus type I and Epstein-Barr virus-transformed lymphocytes acts as an autocrine growth factor and synergizes with interleukin 1 and interleukin 2 . factor and synergizes with interleukin 1 1 acad Sci USA 1990;87:8282-6.

11 Iwata S, Hori T, Sato N, et al. Thiol-mediated redox regulation of lymphocyte proliferation. Possible involvement of adult $\mathrm{T}$ cell leukemia-derived factor and glutathione in transferrin receptor expression. F Immunol 1994;152:563342 .

12 Matthews J, Wakasugi N, Virelizier JL, et al. Thioredoxin regulates the DNA binding activity of NF- $\mathrm{KB}$ by reduction of a disulphide bond involving cysteine 62. Nucleic Acids Res 1992;20:3821-30.

13 Okamoto $\mathrm{T}$, Ogiwara H, Hayashi $\mathrm{T}$, et al. Human thioredoxin/adult $\mathrm{T}$ cell leukemia-derived factor activates the enhancer binding protein of human immunodeficiency virus type 1 by thiol redox control mechanism. Intern Immunol 1992;4:811-9.

14 Hirota $\mathrm{K}$, Matsui M, Iwata S, et al. AP-1 transcriptional activity is regulated by a direct association between thioredoxin and Ref-1. Proc Natl Acad Sci USA 1997;94:3633-8.

15 Sharma OP. Pulmonary sarcoidosis and corticosteroids. Am Rev Respir Dis 1993;147:1598-600.

16 Kogaki H, Fujiwara Y, Yoshiki A, et al. Sensitive enzymelinked immunosorbent assay for adult T-cell leukemiaderived factor and normal value measurement. f Clin Lab Anal 1996;10:257-61.

17 Mizel SB. Interleukin 1 and $\mathrm{T}$ cell activation. Immunol Rev 1982;63:51-72.

18 Hunninghake GW. Release of interleukin-1 by alveolar macrophages of patients with active pulmonary sarcoidosis. $\mathrm{Am}$ Rev Respir Dis 1984;129:569-72.

19 Muler-Quernheim J, Pfeifer S, Mannel D, et al. Lungrestricted activation of the alveolar macrophage/monocyte restricted activation of the alveolar macrophage/monocyte 145:187-92.

20 Depper JM, Leonardo WJ, Drogula C, et al. Interleukin 2 (IL-2) augments transcription of the IL-2 receptor gene. Proc Natl Acad Sci USA 1985;82:4230-4.

21 Devergne O, Emilie D, Peuchmaur M, et al. Production of cytokines in sarcoid lymph nodes: preferential expression of interleukin- $1 \beta$ and inteferon- $\gamma$ genes. Hum Pathol 1992; 23:317-23.

22 Muler-Quernheim J, Saltini C, Sondermeyer P, et al. Compartmentalized activation of the interleukin 2 gene by lung Tymphocytes in active pulmonary sarcoidosis. F Immunol 1986;137:3475-83.

23 Bellocq A, Lecossier D, Pierre-Audigier C, et al. T cell receptor repertoire of $\mathrm{T}$ lymphocytes recovered from the lung and blood of patients with sarcoidosis. Am $\mathcal{F}$ Respir Crit Care Med 1994;149:646-54.

24 Zissel G, Baumer I, Fleischer B, et al. TCR Vb families in T cell clones from sarcoid lung parenchyma, BAL, and blood. Am F Respir Crit Care Med 1997;156:1593-1600.

25 Taniguchi Y, Taniguchi-Ueda Y, Mori K, et al. A novel promoter sequence is involved in the oxidative stress-induced expression of the adult T-cell leukemia-derived factor (ADF)/human thioredoxin (Trx) gene. Nucleic Acids Res 1996;24:2746-52.

26 Furuke K, Nakamura H, Hori T, et al. Suppression of adult $\mathrm{T}$ cell leukemia-derived factor/human thioredoxin induction by FK506 and cyclosporin A: a new mechanism of immune modulation via redox control. Intern Immunol 1995; 7:985-93.

27 Endoh M, Kunishita T, Tabira T. Thioedoxin from activated macrophages as a trophic factor for central cholinergic neurons in vitro. Biochem Biophys Res Commun 1993;192: 760-5.

28 Calhoun WJ, Salisbury SM. Heterogeneity in cell recovery and superoxide production in buoyant, density-defined subpopulations of human alveolar macrophages from healthy volunteers and sarcoidosis patients. F Lab Clin Med 1989;114:682-90.

29 Lakari E, Paakko P, Kinnula VL. Manganese superoxide dismutase, but not $\mathrm{CuZn}$ superoxide dismutase, is highly expressed in the granulomas of pulmonary sarcoidosis and extrinsic allergic alveolitis. Am F Respir Crit Care Med 1998; 158:589-96.

30 Moller DR, Forman JD, Liu MC, et al. Enhanced expression of IL-12 associated with Th1 cytokine profiles in active pulmonary sarcoidosis. F Immunol 1996;156:4952-60.

31 Agostini C, Trentin L, Facco M, et al. Role of IL-15, IL-2, and their receptors in the developement of T cell alveolitis in pulmonary sarcoidosis. F Immunol 1996;157:910-8. 